\title{
Adult Clear Cell Sarcoma of Soft Parts
}

National Cancer Institute

\section{Source}

National Cancer Institute. Adult Clear Cell Sarcoma of Soft Parts. NCI Thesaurus. Code C27370.

A clear cell sarcoma of soft parts occurring during adulthood. 